\title{
GROUND-WATER LEVELS AND FLOW NEAR THE INDUSTRIAL EXCESS LANDFILL, UNIONTOWN, OHIO
}

By E. Scott Bair and S. E. Norris

U.S. GEOLOGICAL SURVEY

Open-File Report 89-272

Prepared in cooperation with the

AGENCY FOR TOXIC SUBSTANCES AND

DISEASE REGISTRATION

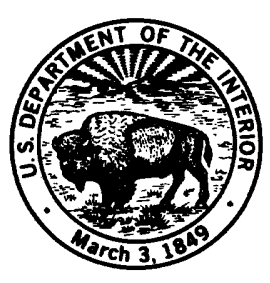

Columbus, Ohio

1989 
DEPARTMENT OF THE INTERIOR

MANUEL LUJAN, JR., Secretary

U.S. GEOLOGICAL SURVEY

Dallas L. Peck, Director

For additional information write to:

Copies of this report can be purchased from:

District Chief

Water Resources Division

U.S. Geological Survey

$975 \mathrm{~W}$. Third Avenue

Columbus, $\mathrm{OH}$ 43212-3192

U.S. Geological Survey

Books and Open-File Reports

Box 25425, Building 810

Federal Center

Denver, CO 80225 
CONTENTS

Abstract 1

Introduction 2

Background 2

Physical setting 3

Ground-water levels and flow 7

Suggestions for additional work 10

Selected references 11

\section{ILLUSTRATIONS}

Figure 1. Map showing the Industrial Excess Landfill

(IEL) site area in Stark County, Ohio

(In pocket)

2. Generalized north-south geologic section based on

logs immediately west of the IEL site 5

3. Generalized east-west geologic section based

on logs immediately south of the IEL site 6

4. Top-of-bedrock map based on drillers' logs

(In pocket)

5-6. Maps showing composite potentiometric surfaces

of aquifers near the IEL site:

5. Bedrock aquifer (In pocket)

6. Glacial-drift aquifer (In pocket)

\section{CONVERSION FACTORS}

For the convenience of readers who may prefer metric

(International System) units to the inch-pound units in this report, values may be converted by use of the following

factors:

Multiple inch-pound unit By

mile ( $\mathrm{mi}$ )

foot ( $f t$ )

gallon (gal)

barrel (bbl)

ton
1.609

2.590

3.785

0.1590

0.9072
To obtain metric unit

kilometer ( $\mathrm{km}$ )

square kilometer $\left(\mathrm{km}^{2}\right)$

liter (L)

cubic meter $\left(\mathrm{m}^{3}\right)$

megagram (Mg) 


\title{
GROUND-WATER LEVELS AND FLOW NEAR THE INDUSTRIAL EXCESS LANDFILL, UNIONTOWN, OHIO
}

\author{
By E.Scott Bair and S. E. Norris
}

\begin{abstract}
Under an interagency contractual agreement with the Agency for Toxic Substances and Disease Registration, the U.S. Geological Survey evaluated geologic and hydrogeologic data available for the Industrial Excess Landfill (IEL) site in Uniontown, Ohio. During previous studies, ground-water contamination was detected in observation wells installed at the site and in residential wells near the site.
\end{abstract}

Water levels recorded on drillers' logs from 279 wells were used to characterize the regional ground-water flow system in the area of the IEL site. On the basis of the gross lithologic differences between the unconsolidated glacial-drift materials and the indurated bedrock, and the inferred differences in their hydraulic properties, the flow system in the area of the IEL site was divided into two regional aquifers: a shallow, unconfined glacial-drift aquifer and a deeper, semiconfined bedrock aquifer. About 33 percent of the drillers' logs were from wells completed in the glacial-drift aquifer, whereas 67 percent were from wells completed in the bedrock aquifer.

A composite potentiometric-surface map of the glacial drift aquifer shows that the IEL site appears to straddle a prominent ground-water ridge that trends northeast-southwest. Ground water flows radially away from this ridge, primarily to the northwest and to the southeast; as a result, flow in the glacial-drift aquifer as the IEL site moves in a radial pattern away from the site in all directions. A composite, regional potentiometricsurface map of the bedrock aquifer shows a similar elongated ground-water ridge trending northeast-southwest across the northwestern corner of the IEL site; however, it does not appear that the IEL site straddles the ground-water ridge in the bedrock potentiometric surface.

As a consequence of the radial-type of flow pattern in the glacial-drift aquifer at the IEL site, the direction of potential off-site movement of a contaminant would, in large part, depend on the original location of the contaminant at the IEL site. This radial type of flow pattern may explain the nonuniform distribution of some of the contaminants detected in observation wells and residential wells, particularly if specific contaminants were not disposed of uniformly across the site. 
Available data also indicate a downward flow component within the glacial-drift aquifer, as manifested by a reduction of hydraulic heads with increasing depth of wells near the site. Such downward flow is consistent with the presence of the ground-water ridge, which would serve as a local recharge area within the regional flow system. Consequently, contaminants present at the site will flow both laterally within the local flow patterns and vertically downward within the flow system.

\section{INTRODUCTION}

\section{Background}

In December 1984, the U.S. Environmental Protection Agency (USEPA) authorized performance of a Remedial Investigation Feasibility study (RI/FS) at the Industrial Excess Landfill (IEL) site in Uniontown, Ohio. The primary purposes of the RI/FS study were site characterization and data collection. During these studies and in another study by the Ohio Environmental Protection Agency (Ohio EPA), ground-water contamination was detected in observation wells installed at the site and in residential wells located in the vicinity of the site.

Under an interagency contractual agreement with the Agency for Toxic Substances and Disease Registration, the U.S. Geological Survey evaluated geologic and hydrogeologic data available from the RI/FS, and from U.S. Geological Survey data bases, with emphasis on how well the available data describe ground-water flow within and around the IEL site.

The IEI is a closed sanitary landfill located in northeastern Ohio, about 10 miles southeast of Akron, in Lake Township, Stark County, adjacent to Uniontown (fig. 1, in pocket). The IEL site covers approximately 30 acres in a rural residential area. The site was a sand and gravel quarry until 1966. The excavation remaining after aggregate mining ceased was converted into a landfill that received a variety of industrial, commercial, and municipal wastes until it was closed in 1980 pursuant to a courtordered consent agreement (U.S. Environmental Protection Agency, 1988). Available information indicates that 80 to 85 percent of the property is underlain by buried wastes.

From 1966 through 1968, the landfill operated under a conditional license and accepted various municipal, commercial, and industrial wastes containing hazardous substances of largely undetermined and unknown composition (U.S. Environmental Protection Agency, 1988). In 1968, Lake Township zoning licenses were issued allowing a variety of solid-waste materials to be disposed of at the site. A solid-waste-disposal license was issued in 
1969, and was reviewed annually by the Ohio Department of Health from 1968-72 and by the Ohio EPA from 1972-80. According to Ohio EPA, the IEL received industrial waste primarily from the rubber industry in Akron, but reports also document receipt of general household wastes and wastes from hospitals and septic-tank cleaning firms (U.S. Environmental Protection Agency, 1988).

Ohio EPA estimated that about 780,000 tons of waste was buried at the site. Information solicited from potentially responsible parties indicate that they disposed of nearly 1,000,000 gallons of waste at the site. In addition, substantial quantities of chemical and liquid wastes were dumped on the ground at the site either from 55-gallon drums and from tank trucks (U.S. Environmental Protection Agency, 1988). Information from the potentially responsible parties indicates that about 60,000 barrels of liquid waste were dumped on the ground at the site, 25 percent of which was believed to be liquid latex. The composition of the other 75 percent is not known. Liquid wastes commonly were mixed with fly ash and deposited on the ground. An evaporation lagoon also was used for the disposal of liquid wastes.

In January 1972, the Stark County Board of Health ordered cessation of disposal of chemical (liquid) waste at the IEL site. In 1980, the Stark County Board of Health and the Stark County Court of Common Pleas ordered closure of the facility. A closure plan was developed, approved, and implemented. Subsequent to closure, gas-monitoring activities by various organizations indicated elevated concentrations of methane gas around the site.

In 1984, the USEPA proposed that the IEL site be put on the National Priorities List. An RI/FS work assignment was issued in December 1984 and work began in 1985. Available reports and other information on the site and the adjacent area are listed under the selected references.

\section{Physical Setting}

The IEL site borders a strip of residential and commercial properties on the west, Metzger ditch and agricultural land on the east, residential property on the north, and agricultural land on the south. Topographic relief at the site is approximately 60 feet. The site was graded and sloped to promote runoff to Metzger ditch. The highest elevation on the site, approximately 1,180 feet above sea level, is in the northwestern part, whereas the lowest elevation, approximately 1,120 feet above sea level, is in the southeastern part along Metzger ditch. 
The site is located in an area of hummocky terrain consisting of irregularly shaped knolls and hills that commonly are underlain by deposits of sand and gravel. Undrained depressions also are common. The northern part of stark County is within the glaciated part of the Appalachian Plateaus physiographic province. The thickness of glacially derived material in the area of the IEL site ranges from about 50 feet to more than 100 feet. These materials consist predominantly of interbedded sand and gravel with minor amounts of silt and clay that were deposited during the Wisconsinan glaciation. In the Uniontown area, these deposits are water bearing and commonly function as a source of residential, commercial, and industrial water.

Although the Pleistocene Kent Till and the Mogadore Till have been mapped in Stark County, it is not known whether either till is present at the IEL site. Geologic sections were prepared by the U.S. Environmental Protection Agency (1988) from soil-boring logs from drilling of observation wells at and adjacent to the IEL site and from data available from water-well drillers' logs for nearby wells. Figure 2 is a north-south geologic section constructed from logs immediately west of the IEL site, whereas figure 3 is an east-west geologic section constructed from logs immediately south of the IEL site. Note that most of the glacial material adjacent to the site consists of sand and gravel. Minor, discontinuous lenses of clay, and silt with sand and clay, also are present. The deposits are thought to be part of a kamemoraine complex (White, 1984).

The glacial deposits are underlain by the Pottsville Formation, a Pennsylvanian sequence of interbedded sandstone, shale, siltstone, limestone, and coal. In the area of the IEL site, the Pottsville Formation is about 400 feet thick. The sandstone and shale units also are used as a residential water source in the Uniontown area.

The bedrock surface in the Uniontown area generally represents the preglacial topography, which appears to have been characterized by moderate relief, steep slopes, and narrow ridges that separated deeply incised streams (Delong and White, 1963). Glacial erosion has modified the bedrock surface, generally forming wide bedrock valleys and broad ridges with rounded hills. A topof-bedrock map (fig. 4, in pocket) was constructed from more than 200 drillers' logs from the area surrounding the IEL site. A similar map, but for the immediate vicinity of the IEL site, was prepared by the U.S. Environmental Protection Agency (1988, fig. 4-3, page 9/128, section 4.2.3). Both maps show an eastwardtrending bedrock valley that underlies the IEL site. The area just north of the IEL site appears to represent a bedrock knoll. Relief between the top of the bedrock knoll and the bottom of the bedrock valley underlying the IEL site is nearly 80 feet. 


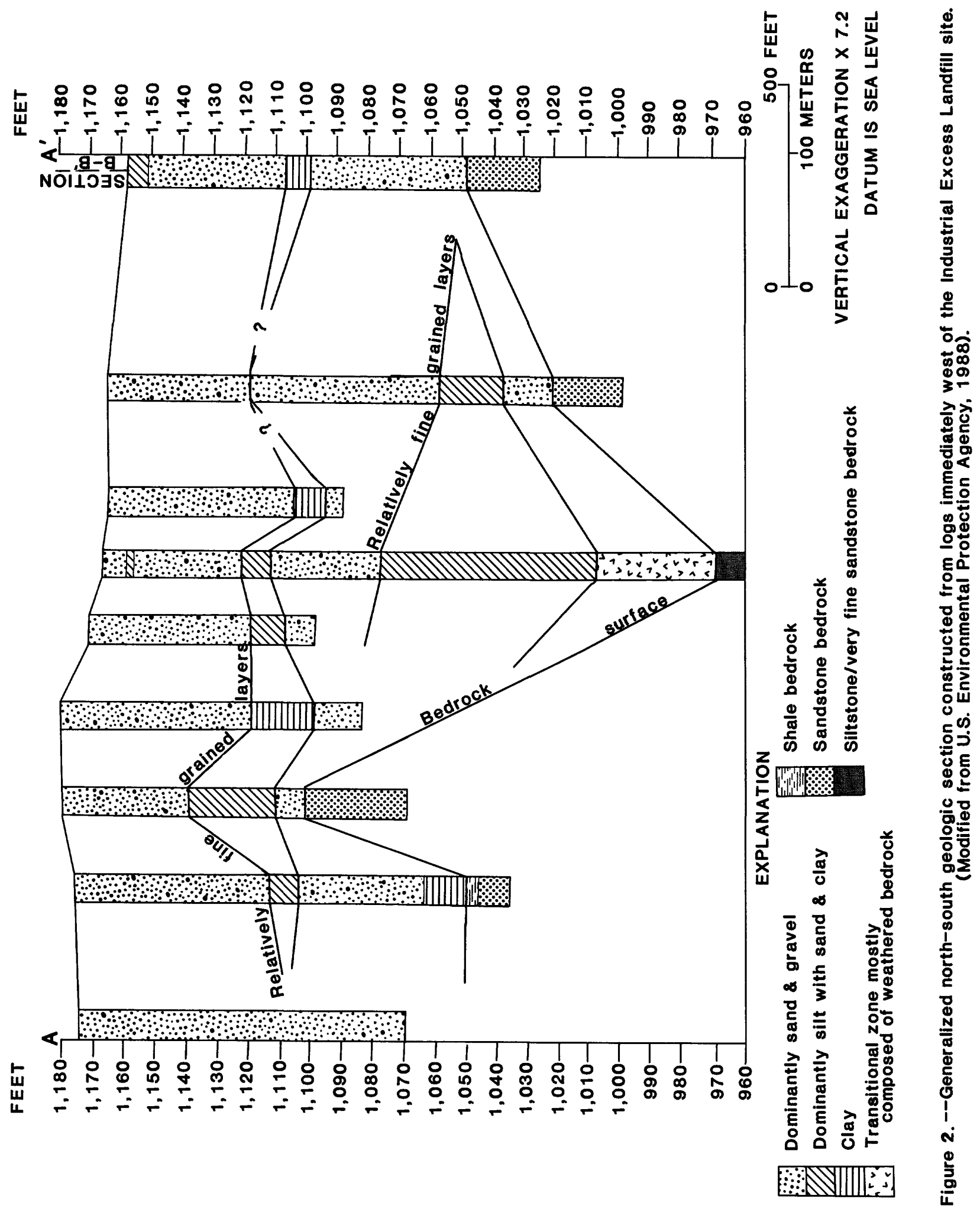




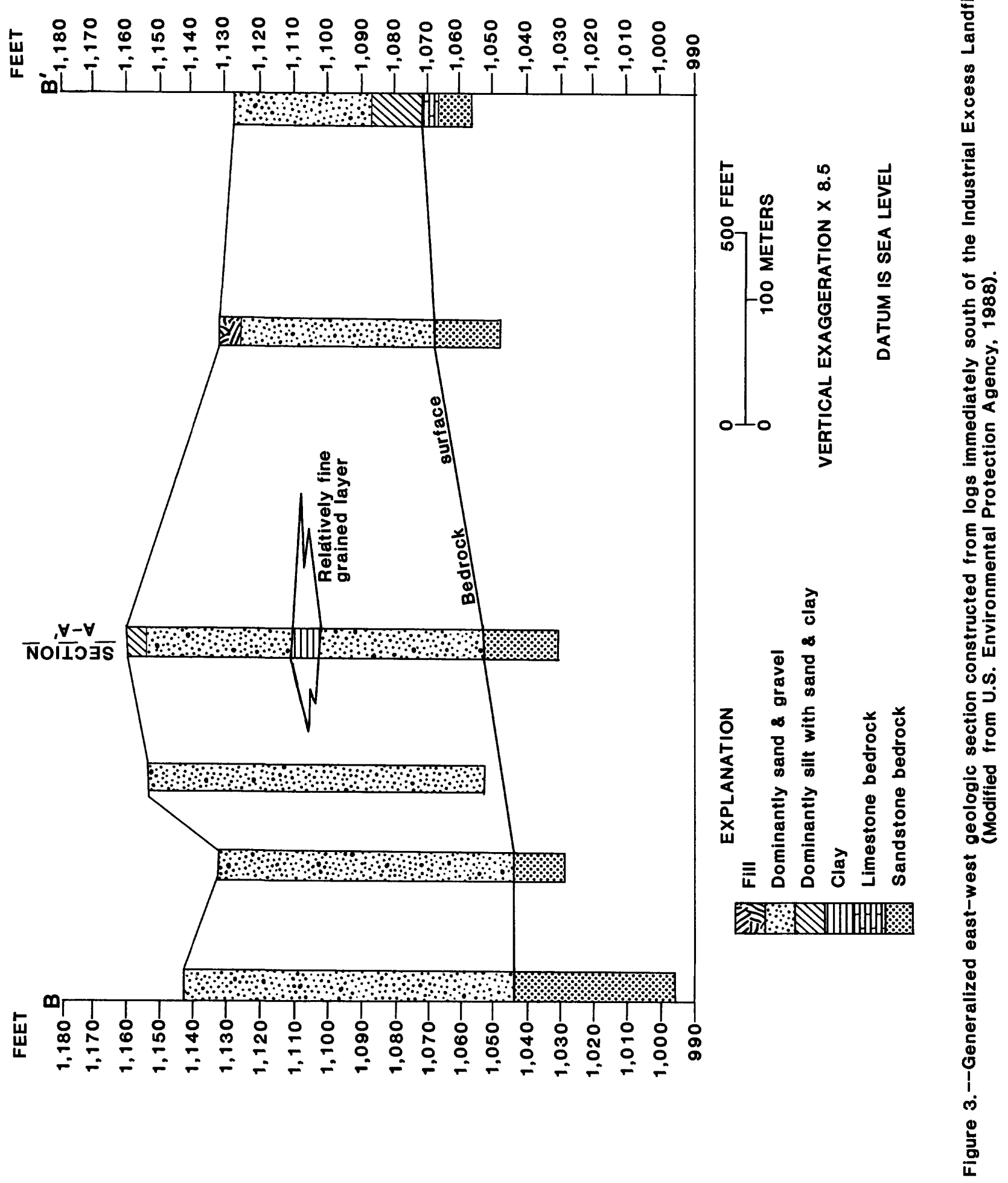


The drillers' logs indicate that the shallowest bedrock commonly consists of either shale or sandstone. Because of the shallow southeastward regional dip, differences in the lithology of the shallowest bedrock unit probably reflect either differences in the depth of erosion or facies changes in the Pottsville Formation. The drillers' logs also commonly indicate the presence of one or more local, thin limestone beds.

\section{GROUND-WATER LEVELS AND FLOW}

Water levels recorded on drillers' logs were used to assess the regional ground-water flow system in the area of the IEL site. Drillers' logs from 279 wells were examined to determine the completion depth of the well, the lithology of the open/screened interval, and the reliability of the recorded water level.

On the basis of the gross lithologic differences between the unconsolidated glacial-drift materials and the indurated bedrock, and the inferred differences in their hydraulic properties, the flow system in the area of the IEL site was divided into two regional aquifers: a shallow, unconfined glacial-drift aquifer and a deeper, semiconfined bedrock aquifer. About 33 percent of the drillers' logs were from wells completed in the glacial-drift aquifer, whereas 67 percent were from wells completed in bedrock.

A total of 93 wells were completed in the glacial-drift aquifer. Water levels recorded on the drillers' logs from five of these wells were considered to be unreliable. Another eight wells were outside the area shown on figure 5 (in pocket). The geographic distribution of the remaining 80 wells is shown on figure 5.

A total of 186 wells were completed in the bedrock aquifer. The lithology of the open interval of these wells is as follows: shale, 38 wells; shale underlain by sandstone, 90 wells; sandstone, 52 wells; sandstone underlain by shale, 6 wells. Water levels from 17 bedrock-well logs were judged to be unreliable. Another six wells were outside the area shown in figure 6 (in pocket). The geographic distribution of the remaining 163 wells is shown on figure 6 .

In addition to the water levels recorded on the well logs, water levels in 25 residential wells were measured by Ohio EPA in March 1984 (Mohr and Khourey, 1984), and water levels in 23 observation wells at or near the IEL site were measured by the U.S. Geological Survey in January 1988.

The depth-to-water measurements recorded on the drillers' logs were converted to water-level elevations relative to sea level by estimating the collar elevation of the well using topographic maps of stark County with a 2-foot contour interval 
and a scale of $1: 24,000$. Wells whose position could not be located on these maps were field located and added to the data base. The region of study encompasses about 4 square miles; the IEL site is located slightly northwest of the region's approximate center.

Although water levels recorded on the drillers' logs include temporal variations and may not be measured precisely, the flow patterns shown on potentiometric surfaces constructed from these data are consistent with regional hydrodynamic principles and with local water levels measured in the area of the IEL site. On the basis of five sets of water-level measurements made over a 13month period, figure 4-13 of the Final Remedial Investigation Report (U.S. Environmental Protection Agency, 1988) shows that water levels at the IEL site in the glacial-drift aquifer and in the bedrock aquifer vary only slightly over time. The maximum amplitude of water-level change in any of the observation wells was slightly less than 1 foot. This limited amount of data indicates that inclusion of nonsynoptic water-level measurements probably would not introduce gross errors in the general interpretation of regional flow patterns in the area of the IEL site.

Figure 5 is a composite potentiometric surface of the glacial-drift aquifer. It is based on water levels measured in 80 wells from April 1962 through January 1988. As can be seen from the equipotential lines, a prominent ground-water ridge trends northeast-southwest across the northwestern corner of the IEL site. Ground water flows radially away from this ridge, primarily to the northwest and to the southeast. The ground-water ridge corresponds to a topographic ridge oriented in the same direction, as shown on figure 1 .

The IEL site appears to straddle the ground-water ridge. As a result, flow in the glacial-drift aquifer at the IEL site moves in a radial pattern away from the site in all directions and across the eastern, northern, western, and southern borders of the IEL site. This flow pattern also is shown in the more localized potentiometric surface of the shallow observation wells in the area of the site (U.S. Environmental Protection Agency, 1988, fig. $4-9$, p.21/128 in section 4).

A composite, regional potentiometric surface also was constructed for the bedrock aquifer from 163 water levels recorded on drillers' logs from February 1953 through January 1988. Figure 6 shows a similar elongated ground-water ridge trending northeastsouthwest across the northwestern corner of the IEL site. In the area of the IEL site, flow patterns in the bedrock aquifer appear to be similar to those in the glacial-drift aquifer; however, on 
the basis of the available well control, it does not appear that the IEL site straddles the ground-water ridge in the bedrock potentiometric surface. Another difference in the two potentiometric surfaces is the presence of a small potentiometric mound due north of the IEL site with 20 feet of relief.

The water-level data plotted on figure 4-13 in the Final Remedial Investigation Report (U.S. Environmental Protection Agency, 1988) and the water-level data measured at the IEL site by the U.S. Geological Survey (fig. 6) generally indicate a downward flow component from the shallow observation wells to the deep observation wells, as manifested by a reduction of hydraulic heads in wells with increasing depth. This is consistent with the location of the IEL site along a ground-water ridge, which would serve as a local recharge area within the regional flow system.

As a consequence of the radial-type of flow pattern in the glacial-drift aquifer at the IEL site (fig. 5), the direction of potential off-site movement of a contaminant would, in large part, depend on the original location of the contaminant at the IEL site. For example, if contaminant $A$ were to intercept the water table in the northwestern corner of the site, it would flow to the northwest away from the site. However, if contaminant $B$ were to intercept the water table in the southern part of the site, it would flow to the southwest away from the site. As a result of this flow pattern, contaminant $A$ would be found in the northwestern part of the study area but not in the southwestern part, and contaminant $B$ would be found in the southwestern part of the study area but not in the northwestern part. This radial type of flow pattern may explain the nonuniform distribution of some of the contaminants detected in observation and residential wells, particularly if specific contaminants were not disposed of uniformly across the site. It is highly unlikely that specific contaminants were disposed of uniformly across the site.

The vertical movement of contaminants within the glacial-drift aquifer is controlled by the vertical hydraulic gradient within the glacial materials. Water-level measurements made by the U.S. Geological Survey in January 1989 in 23 observation wells at or near the IEL site indicate that a downward component of flow exists between the shallow observation wells and the intermediatedepth observation wells. Both sets of wells are completed in the glacial-drift aquifer. A comparison of water levels in the shallow observation wells with those in the deep observation wells, which are completed in the bedrock aquifer, also indicates a downward component of flow. Consequently, contaminants present a the site will flow both laterally within the local flow patterns indicated on figures 5 and 6 and vertically downward within the flow system. 
The amount of vertical flow depends on the vertical hydraulic gradient, the ratio of vertical to horizontal hydraulic conductivity of the various aquifer materials, and the chemical properties of the particular contaminant. At present, no data are available concerning the vertical hydraulic conductivity ( $\mathrm{K}_{\mathrm{V}}$ ) of the

glacial-drift aquifer at the IEL site. This information can only be determined from an aquifer test. Slug tests, which were the only type of hydraulic test performed at the IEL site, are not useful for determining values of $\mathrm{K}_{\mathrm{V}}$.

\section{SUGGESTIONS FOR ADDITIONAL WORK}

The number of domestic wells along the eastern and southern borders of the immediate site area is insufficient to make any reliable interpretations concerning flow directions in either the glacial-drift aquifer or the bedrock aquifer. Acquisition of water-level data in these areas would improve estimates of flow directions and rates of contaminant-migration in these area.

An improved understanding of the regional flow patterns in the Uniontown, Ohio, area could be made if a synoptic set of waterlevel measurements were made. This would be particularly worthwhile if additional observation wells were constructed.

Within the framework of the ground-water flow patterns previously described, the rate of movement of contaminants away from the IEL site is controlled, in large part, by spatial variations in the advective transport velocity (average linear flow velocity) of the local flow system. These variations reflect differences in the horizontal hydraulic gradient and the horizontal hydraulic conductivity $\left(\mathrm{K}_{\mathrm{h}}\right)$. Temporal variations in hydraulic gradient are considered to be minor and, therefore, to have only a minor influence on rates of contaminant movement.

$K_{h}$ values for the glacial-drift aquifer and the bedrock aquifer at the IEL site were determined by performing slug tests in the observation wells. This method does not put a sufficient stress on the aquifer tested to obtain representative values of $\mathrm{K}_{\mathrm{h}}$. The $\mathrm{K}_{\mathrm{h}}$ values obtained from this method represent a "point permeability" measurement. An improved estimate of the $\mathrm{K}_{\mathrm{h}}$ of the glacial-drift aquifer could be obtained from an aquifer test performed at the site. The aquifer test also would enable estimation of $\mathrm{K}_{\mathrm{V}}$. This information, along with additional water-level data from new additional observation wells located to the east and south of the IEL site, would improve understanding of the rates of contaminant movement at the site.

Many organic contaminants are attenuated by organic material in soil horizons, in unconsolidated materials, and, to a lesser extent, in lithified rocks. Data need to be collected to deter- 
mine variations in the total organic-carbon content of the glacial-drift aquifer and the unsaturated zone. This information would enable estimation of contaminant migration rates based on a more realistic method than on mere calculations of the average linear flow velocity.

\section{SELECTED REFERENCES}

Camp, Dresser, \& McKee, Inc., 1986, Geophysical survey investigations at Industrial Excess Landfill (prepared for C. C. Johnson \& Associates), $16 \mathrm{p}$.

-1987, Addendum to geophysical survey at Industrial Excess Landfill (prepared for C. C. Johnson \& Malhotra), $17 \mathrm{p}$.

Camp, Dresser, \& McKee Federal Programs Corporation, 1987. Focused feasibility study for evaluating alternative water supplies at the Industrial Excess Landfill, Uniontown, Ohio (prepared by C.C. Johnson \& Malhotra).

Delong, R. M., and White, G. W., 1963, Geology of Stark County, Ohio: Ohio Department of Natural Resources Division of Geological Survey.

Mohr, E. T., and Khourey, C. J., 1984, Report on sampling of residential well water supplies in the vicinity of the Industrial Excess Landfill, Uniontown, Ohio: Ohio Environmental Protection Agency, Northeast District Office, $17 \mathrm{p}$.

U.S. Environmental Protection Agency, 1985, Performance of remedial response activities at uncontrolled hazardous-waste sites (REM II) prepared by C. C. Johnson \& Associates).

--- 1988, Einal remedial investigation report for Industrial Excess Landfill, Uniontown, Ohio.

White, G. W., 1984, Glacial geology of Summit County, ohio: Ohio Geological Survey Report of Investigations 123, 1 map, 25 p. 


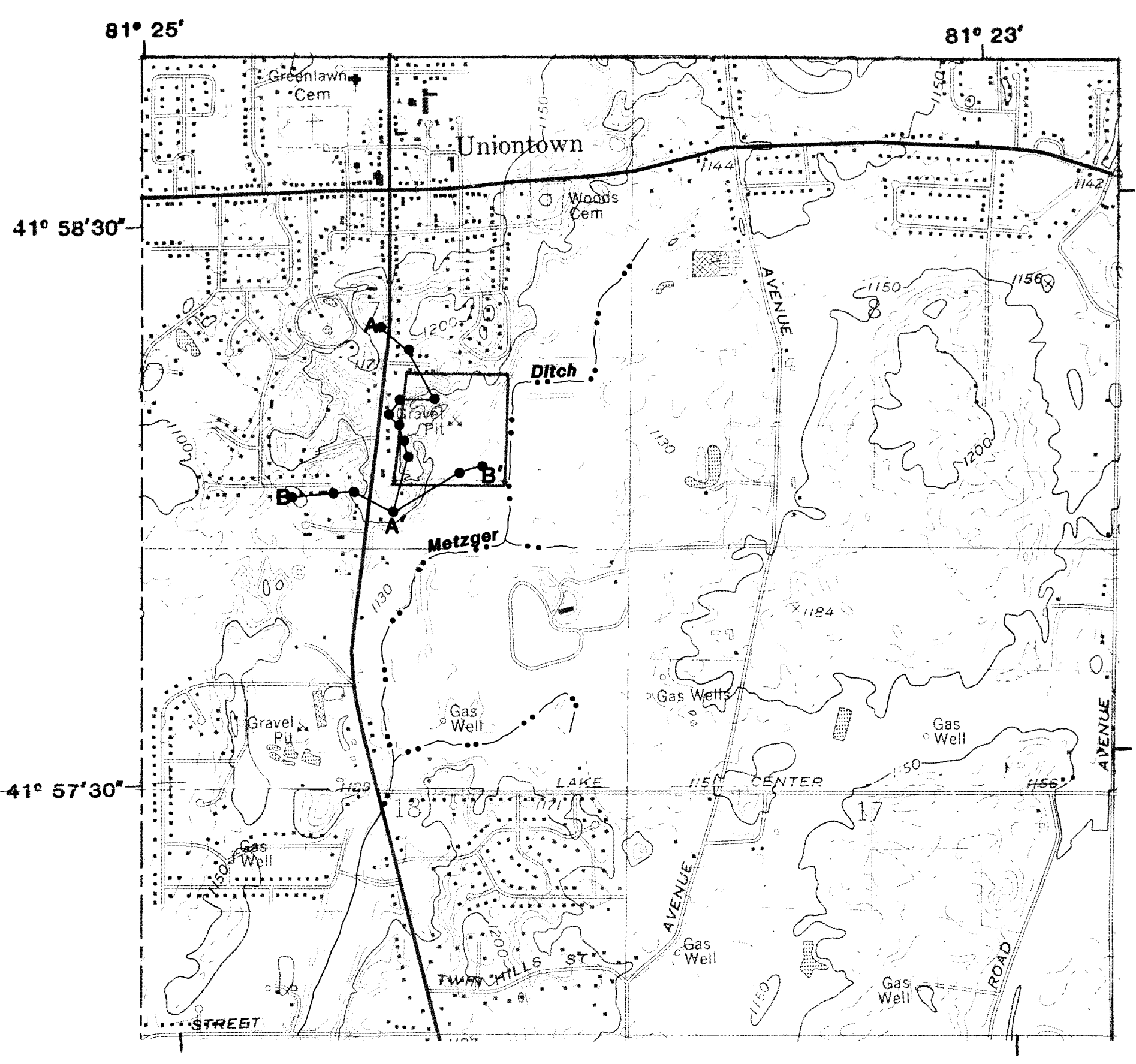

Base from U.S. Geological Survey

North Canton, Ohio, 1:24,000, 1978

EXPLANATION

$A-A^{\prime} \quad$ Locations of geologic sections
$B-B^{\prime}$ shown in figures $2 \& 3$.
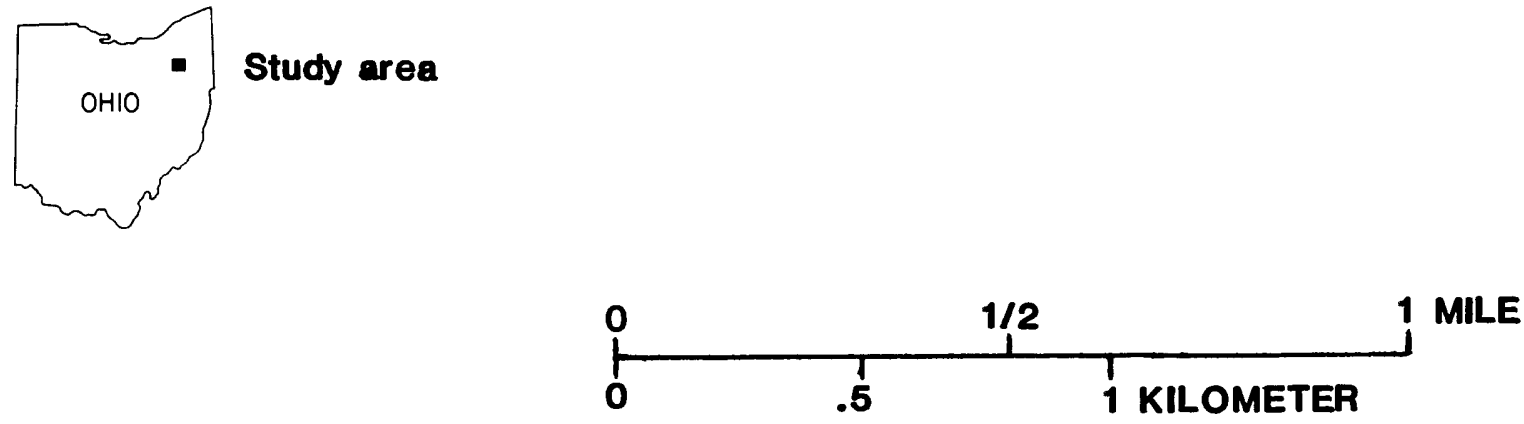

Figure 1.--The Industrial Excess Landfill (IEL) site area in Stark County, Ohio. 


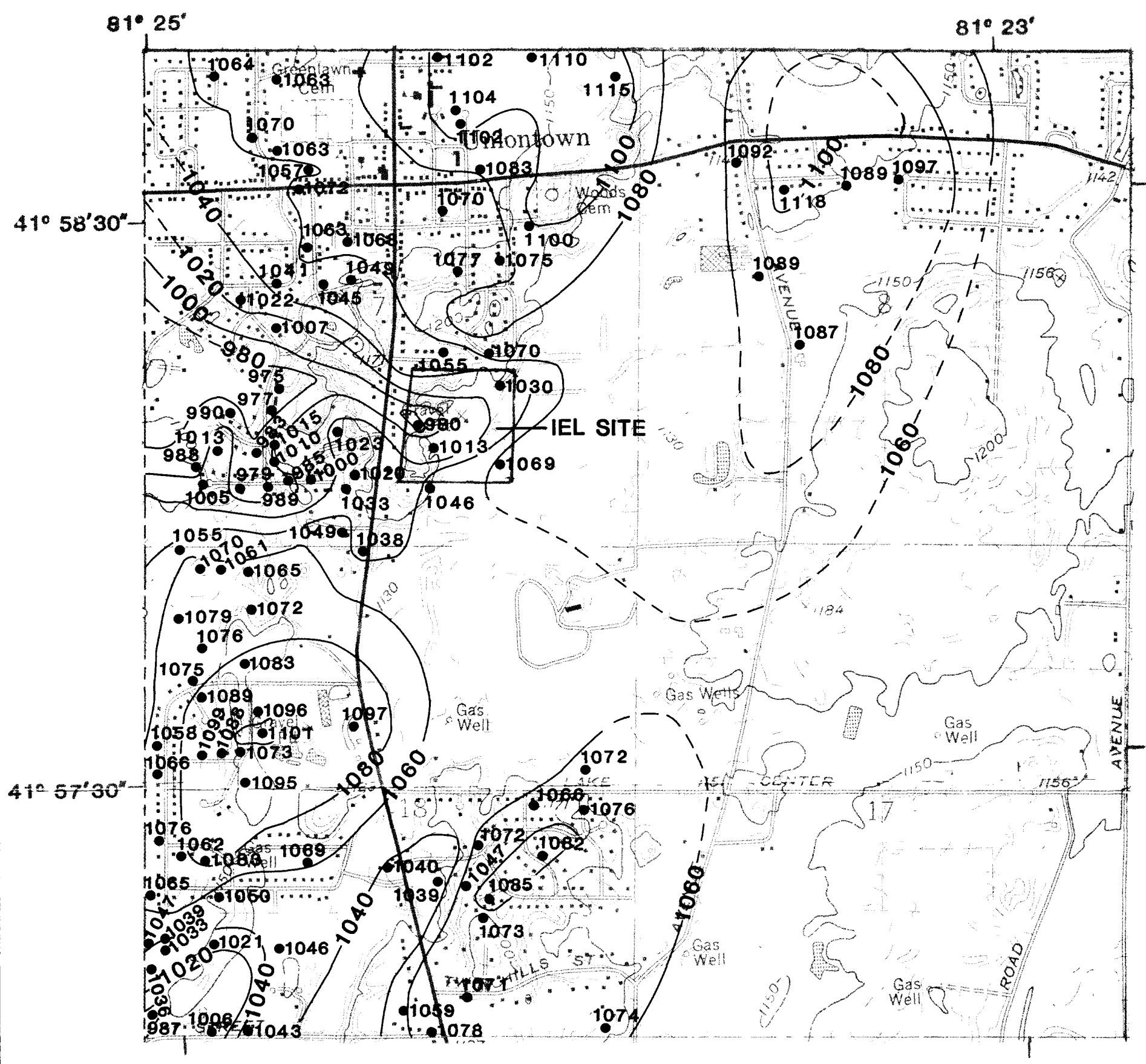

Base from U.S. Geological Survey

North Canton, Ohio, 1:24,000, 1978

EXPLANATION

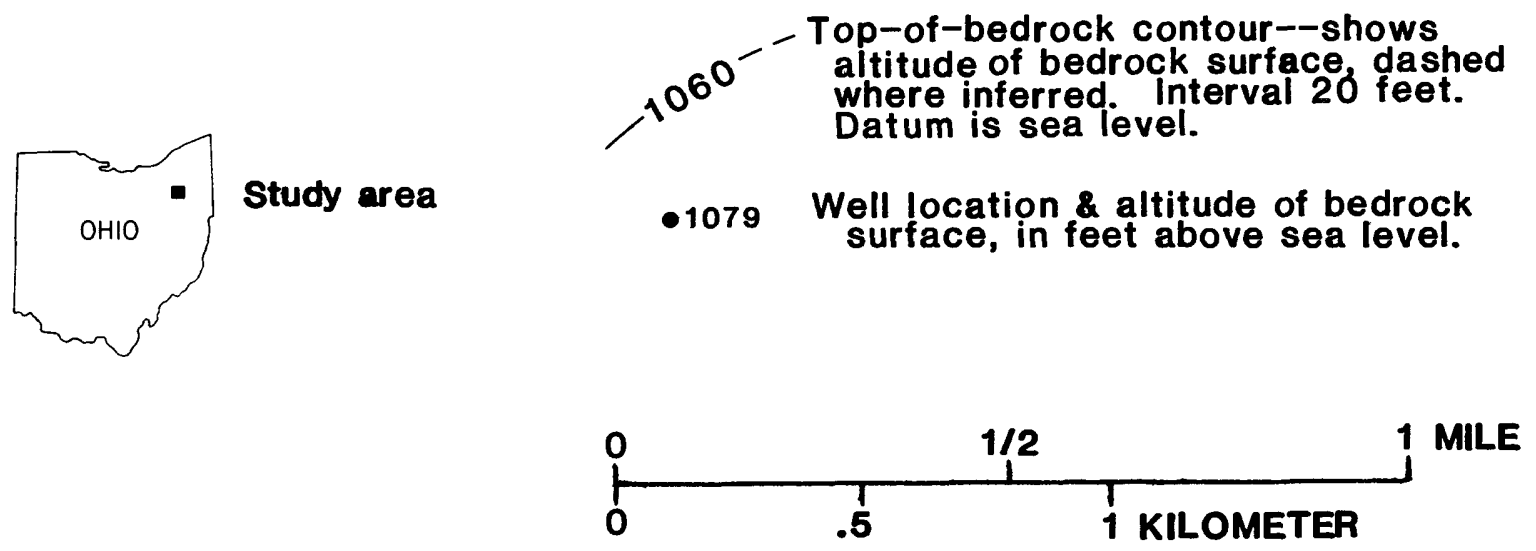

Figure 4.--Top-of-bedrock map based on drillers' logs. 




Base from U.S. Geological Survey

North Canton, Ohio, 1:24,000, 1978

EXPLANATION
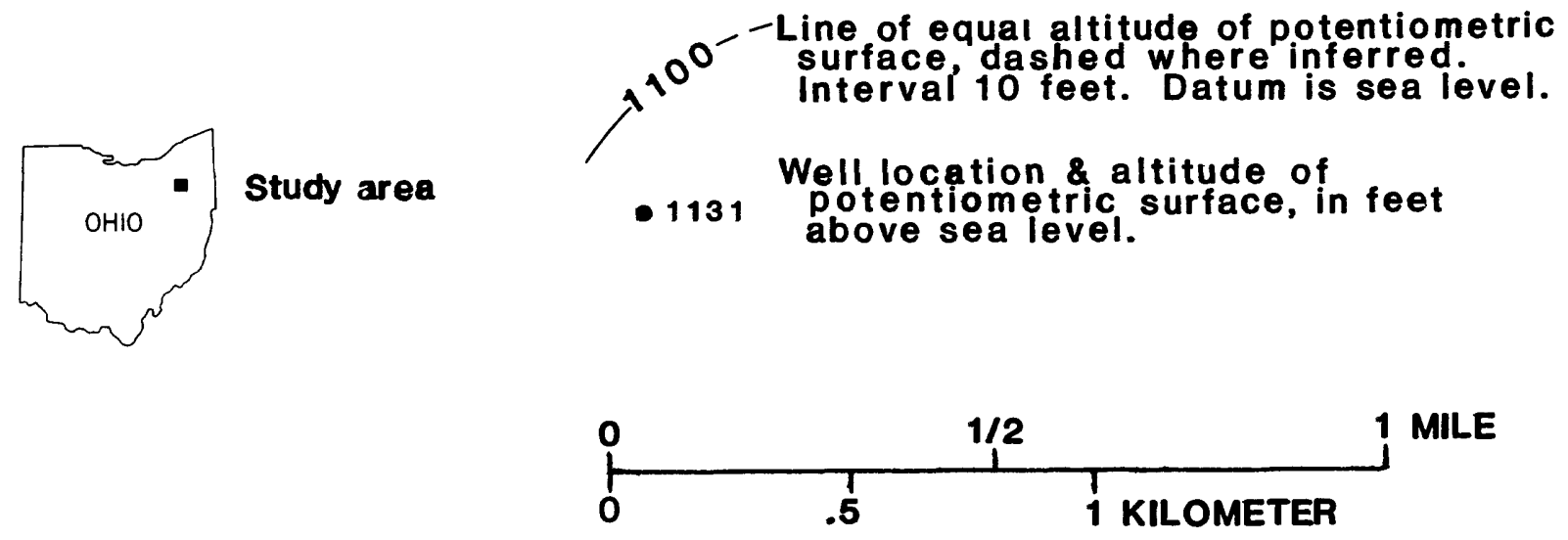

Figure 5.--Composite potentiometric surface of the glacial-drift aquifer near the Industrial Excess Landfill (IEL) site, based on water levels measured from April 1962 through January 1988. 


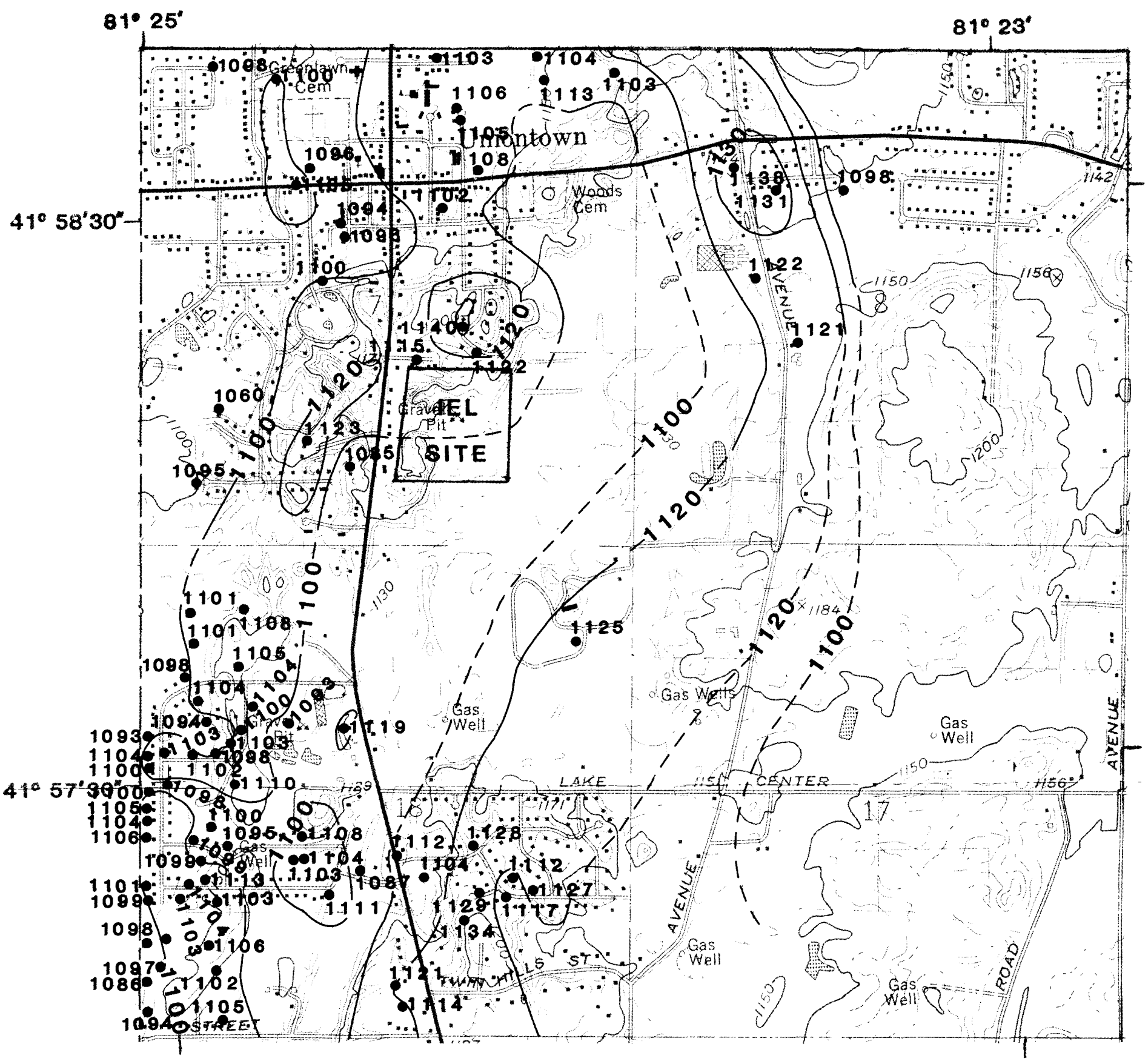

Base from U.S. Geological Survey North Canton, Ohio, 1:24,000, 1978

EXPLANATION
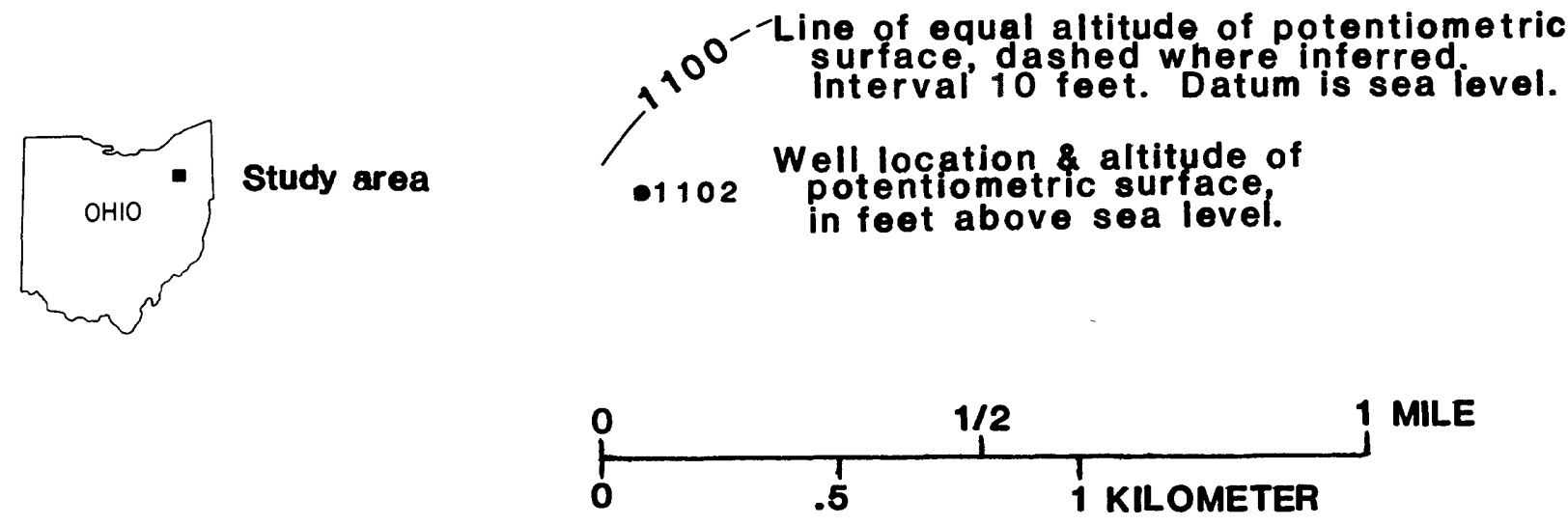

Figure 6.--Composite potentiometric surface of the bedrock aquifer near the Industrial Excess Landfill (IEL) site based on water levels measured from February 1953 through January 1988. 